$\left.\begin{array}{c}\text { Sournals } \\ \text { INTERNATIONAL JOURNAL OF } \\ \text { ORGANIZATIONAL LEADERSHIP }\end{array}\right) \begin{gathered}\text { INDUSTRIAL } \\ \text { MANAGEMENT } \\ \text { INSTITUTE }\end{gathered}$

\title{
The influence of export skills on export performance: A case study of export companies in East Azerbaijan
}

\author{
Roholah Majlesara*1 ${ }^{1}$, Roghaye Afshari ${ }^{2}$, Zahra Ghadimi ${ }^{3}$, \\ Fardin Mohammadi ${ }^{4}$, Nazel Asadi ${ }^{5}$ \\ ${ }^{1,2}$ Department of Management, Novin Higher Education Institute, Ardabil, Iran \\ ${ }^{3}$ University of Moghadas Ardabili, Ardabil, Iran \\ ${ }^{4}$ Department of Management, Shahriyar Higher Education Institute, Astara, Iran \\ ${ }^{5}$ University of Mohaghegh Ardabili
}

\begin{abstract}
Keywords:

This study aims to build a theoretical framework that identifies the influence of export skills

Export, Export Skills, on export performance in export companies in East Azerbaijan, Iran. It also inquires into the Export Performance priority of the skills. The data obtained by a questionnaire filled in by 65 producing-exporting companies in East Azerbaijan. The results of the data analysis indicated that export skills have significant influence on export performance of producing-exporting companies. Based on the results of the data analysis it can be argued that international finance and risk management

Correspondence: skills, international trade research skills, international marketing skills, and international trade

r.majlesara@gmail.com regulations skills are the most effective factors in export performance. The findings of the study and their implications are explained in detail.
\end{abstract}

(C)AIMI Journals

\section{Introduction}

Nowadays, it is obvious that the economic growth and expert of each company are intimately linked. Interestingly enough, international economics theoreticians who highly believe in the role of trade in economic growth are called growth engines (Balassa, 1978). The process of 
international finance has been along with the decreasing of raw materials and agriculture productions and increasing of the rate of industrial export all over the world. The export of industrial products is a reliable source for the guarantee of national production growth and increasing of income. It should be stressed that technology and knowledge of it is of primary importance in industry. Hence, producing and exporting industrial products are based on increasing the knowledge and skills of workers. Thus, export skills are assumed as one of the key factors in promoting export. To be competitive in overseas as well as domestic markets, company managers are required to understand the various practical export skills and their effects on company export performance. In fact, the level of knowledge and skills companies bring and take advantage of them in international marketing activities are key factors in success of companies in international markets.

Although some researchers (Kaynak, 1992; Kedia \& Chhokar, 1986; Koksal, 2006; Li, 2004; Li \& Ogmokun, 2001; Piercy, Kaleka, \& Katsikeas, 1998; Ross \& Whalen, 1999; Ting, Guijun, \& Bojun, 2010) have confirmed that successful export involves some requisite skills, among which practical skills are of great importance, the lack of export knowledge and market information of companies was observed in many countries as documented by Hendrych (1994), Reid (1994), Gancel (1995), Valos and Baker (1996). It is imperative to mention that there is a lack of research investigating the impact of export skills on export performance of Iranian export companies. Therefore, this study firstly aims at building a theoretical framework that identifies the influence of export skills on export performance in export companies in East Azerbaijan, Iran. Secondly, it aims at identifying the export skills that have the most significant effect on export performance of export companies from different business areas and making an empirical ranking of their importance. Also, it can serve as useful information for the export companies and government trade promotion agencies to improve their existing skill training programs.

\section{Literature Review}

The importance of practical skills to successful exporting is indicated by a significant and increasing body of literature. Central capabilities of exporters to achieve long-term success contain acquisition and utilization of export skills (Ross \& Whalen, 1999; Samiee \& Walters, 1999). They are also determinant sources of sustainable competitive advantage (Piercy, Kaleka, \& Katiska, 1998). In the face of the high awareness of its importance, the lack of export knowledge and market information was noticed for companies in many countries 
(Gancel, 1995; Hendrych, 1994; Reid, 1994; Valos \& Baker, 1996). It is observed that no matter how profitable the company was, it did not feel satisfied enough about the procedural expertise (Kotabe \& Czinkota, 1992). Piercy, Kaleka, and Katsikeas (1998) postulated a more explicit linkage between exporting skills and export performance. Figure 1 shows their model of sources of superior performance in exporting.

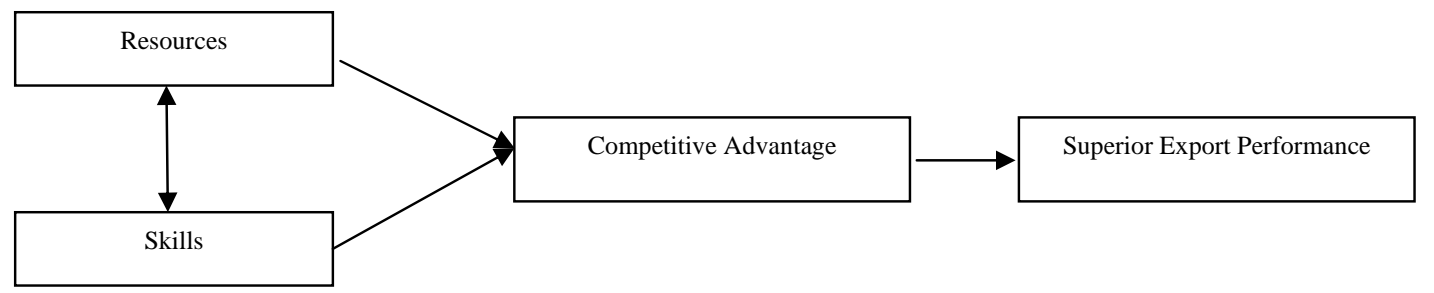

Figure 1. Model of sources of superior performance in exporting

The model displays that along with competitive resources in export, competitive skills in export can be considered as an essential contributor to the company's competitive advantage. Accordingly, this competitive advantage produces superior export performance. Besides, Piercy, Kaleka, and Katsikeas (1998) in their study of UK exporters, found that there is a gap between high and low export performers in the possession of these critical competitive skills in exporting.

Although Kyanak (1992) does not specifically addresses the importance of practical export skill, he puts an emphasis on perceptions of exporters about cost differences between domestic and export markets as well as perceptions of major barriers to export marketing. Costs combined with items namely, selling, packing and handling, shipping, insurance, risk management, and managerial time prescribed to locate customers, negotiate sales, and prepare after-sales service were all rated as being higher for exports in comparison with domestic sales. Additionally, there exist some important barriers to export marketing such as credit limitations, price and quality limitations, delivery problems, freight costs, currency fluctuations, and limited local market knowledge were. Some factors including the higher costs and greater perceived barriers which are combined with these practical skill areas recommend that these companies would consider practical skills as essential elements to their exporting success.

In order to implement export strategies, a number of studies have precisely attempted to identify the particular skill sets. Kedia and Chhokar (1986) observed 96 small and medium 
sized firms - both exporters and non-exporters drawn from a broad cross section of unrelated industries-and requested them to categorize 20 skills that are related to export. Each skill was gained a point in terms of perceived importance and perceived difficulty. In such a manner, as they defined their export skills in broad terms like complying with government regulations, knowing how to market overseas, and minimizing foreign exchange risk, the question of just what specific skills were being measured arises. After all, by identifying their results, significant differences in the perceived importance and abilities between exporters and non-exporters were established-a finding compatible with the findings of Kotabe and Czinkota (1992) considering that in different phase of export development, export training needs differ among exporters.

In order to support the export performance of Canadian companies, the Forum for International Trade Training (FITT) was constructed in 1992 with public funding and trade, labor and industry association sponsorship to accommodate practical export skills training. The FITT skills Certificate Program cover a number of areas. Firstly, it includes global entrepreneurship which involves recognition of the international business environment inclusive of the role of GATT/WTO and other multilateral institutions, trade rules, bilateral trading relationships, tariff treatments and international business planning. Secondly, it contains international marketing such as export marketing principles, market research, market entry strategies, promotional strategies, and pricing. Additionally, international finance is another area which includes risk analysis, export costing, and processing international payments, financing trade, exchange rate management, and cash flow planning. Also, international trade logistics is one of the subordinated areas which contain trade documentation, transportation, health and environmental issues, and customs procedures.

Ross and Whalen (1999) investigated the differences between the practical export skills needed by Canadian Agribusiness for sales to the U.S. with those for overseas markets. In some fields, namely global entrepreneurship, international marketing, international finance, and international trade logistic, seventy skills were categorized and used to study the effect of export market on practical international trade skills. They observed that practical export skill requirements differ extensively by company and export market. In addition, basic management, marketing, finance, and shipping skills were essential factors for having successful agri-product exporting. For most exporters, advanced skills in some fields including strategic management, export marketing, and export finance were not of great importance. Also, Samiei Nasr, Aali, and Bafandeh Zendeh (2011) examined 153 Iranian 
exporting companies in East Azerbaijan, Iran. Six skill categories, by the use of factor analysis, were determined and 49 skills were turned up to be more important. Their findings showed that skills in international finance and risk management, international trade regulations, and international trade research were regarded as being more crucial.

\section{Export Performance}

By doing research on export performance various effective variables have been revealed; however, the form and proportion of the impacts have not been established yet (Chetty \& Hamilton, 1993; Theodosiou \& Leonidou, 2003). When the impact of a given factor that may depend on the specific measure of performance used is taken into account, the issue gets more intricate but none of the existing measures has reached universal acceptance.

Several literature reviews which are related to international business studies demonstrated the most commonly indicated variables used to explain export performance. Aaby and Slater (1989) classified them into four groups, including firm characteristics such as size, managerial commitment, managerial perceptions; firm competences, namely technology, market knowledge, market planning, export policy, control systems, quality control, and communication skills; export strategies such as market selection, use of intermediates, product mix, product development, promotion, pricing, and external environment. Zou and Stan (1998) regarded them either internal or external determinants of export performance. Internal determinants of export performance involve export strategy, managers' perceptions and attitudes, managers' characteristics, firm's characteristics and competences; and external determinants of export performance include industry characteristics, and external and domestic market characteristics. Moini (1995) recommended three broad classes inclusive of organizational characteristics such as size, international experience, and competitive advantages; managers' positive and negative expectations; and managers' characteristics including age, formal education, experience, and knowledge of foreign languages. In addition, we can add a fourth factor, namely systematic search for new external markets. The review of Katsikeas, Leonidou and Morgan (2000) led to two sets of factors, namely target market selection and export strategy which have direct effect on export performance. It also resulted in three sets of factors which might influence export performance, including managers’ characteristics, organizational characteristics, and environmental variables.

Leonidou, Katsikeas and Samiee (2002) found that the impact on export performance differed in relation to the specific facet or measure of export performance selected, and the 
mentioned five types of variables implied to prevail most of the studies, including managers' characteristics, organizational factors, environmental forces, export target, and export marketing strategy. Export performance in the study of Gabriel and Simone (2004) was measured using the three variables which are mentioned below.

\section{Export Sales as a Percentage of Total Corporate Sales}

In many studies conducted to date, a single variable such as export sales as a per cent of total corporate sales was used for measuring export performance, called export intensity (Bijmolt \& Zwart, 1994; Chrisman \& Leslie, 1989; Moini, 1995). Former research has proposed that this variable has a crucial effect on all aspects of export behavior (Bilkey \& Tesar 1978; Cavusgil \& Nevin 1981; Czinkota \& Ursic 1991; Moini, 1995). Export sales are considered as export sales as a percentage of total sales (Burton \& Schlegelmilch, 1987). High involvement companies in comparison with low involvement companies generally realize a greater percentage of total sales from foreign markets (Norvell, Andrus, \& Gogumalla, 1995).

It is perceived that export growth, in terms of whether export sales were declining or increasing, was another element that should be included as one of the variables for measuring export performance. Current financial profitability of an organization's exporting operations was also considered because it is assumed as an indication of export performance.

\section{Research Questions}

The following research questions were addressed in this study:

- Do export skills have an impact on growth of export sales?

- Do export skills have an impact on growth of export profits?

- Do export skills have an impact on expansion of export markets?

- What is the prioritization of export skills?

\section{The Study}

The research sample consists of producing-exporting companies in the East Azerbaijan, Iran. This province is Iran's first and the most important region in terms of the export volume. In 2008, East Azerbaijan province produced 18 per cent and 16 per cent of the country's total non-oil exports and its manufacturing exports, respectively.

After a detailed study of the literature and discussions with five company export managers, the questionnaire was developed. In addition, in order to evaluate the measures 
used in the study, it was reviewed by four academics in the field of export marketing. Based on the received feedback, modifications made to the questionnaire. Then a personalized letter and accompanying questionnaire were sent to export managers and company owners in the 157 companies, sixty-five of them volunteered to participate in the research. Therefore, the study achieved a 42 per cent response rate.

Through a comprehensive review of the export related literature, the survey instrument used for this study was prepared. It takes the form of a structured questionnaire which consists of three major parts. The first part aimed to collect information regarding company's characteristics. The second part referred to the satisfaction of the export performance of companies. Five Likert-point scales, anchored by $1=$ completely satisfied to $5=$ completely dissatisfied were used to measure export performance. The final part of questionnaire included 44 questions to determine the amount of export skills. Five Likert-point scales, anchored by 1 = very much to 5 = very little were adopted. Forty four skills were drawn from Samiei Nasr, Aali, and Bafandeh Zendeh (2011) for the aim of this study. All the skills were primarily classified into six focus areas that covered international trade logistics, international finance and risk management, international marketing, international strategic management, international trade regulations, and international trade research. The questionnaire was distributed to ten exporting companies in Iran, prior to the commencement of the full scale study. This step of pilot test ensured that the ambiguity of wording was minimized. The regression test by SPSS software was used to test the research questions. Also, in order to examine the reliability of items of the questionnaire Cronbach's alpha was run. Reliability coefficient of all questions was over 70 per cent and had an acceptable level.

\section{Results}

Table 1 presents the general profile of the respondent companies. Almost 30.7 per cent of the companies in the sample included companies with 50 employees or fewer, and 23.07 per cent were companies with 51-100 employees. Almost 70 per cent of manufacturing companies were in food and tobacco products and fabricated metal products, machinery, and equipment. According to the results indicated in Table 2 and considering the export skills, the maximum mean related to international strategic management skills was 3.15 and standard deviation was 0.69 . 
Table 1

Profile of Exporting Manufacturing Companies

\begin{tabular}{ccc}
\hline Company Size (employees) & $\mathrm{F}$ & $\mathrm{P}$ \\
\hline 50 employees or fewer & 20 & 30.7 \\
$51-100$ employees & 15 & 23.07 \\
$101-200$ employees & 10 & 15.38 \\
$201-500$ employees & 15 & 23.07 \\
501 employees or more & 5 & 7.69 \\
Sectors & 18 & 27.69 \\
Food and tobacco products & 13 & 20 \\
Textile & 28 & 43.07 \\
Fabricated metal products, machinery and equipment & 6 & 9.23 \\
Leather and leather products & 6 & \\
\hline
\end{tabular}

*Total companies in sample: 65100

The minimum of mean related to international trade logistics skills was 2.20 and standard deviation was 0.70 .

Table 2

Descriptive Statistics Related to Export Skills

\begin{tabular}{|c|c|c|c|c|c|c|}
\hline Statistics & $\begin{array}{c}\text { International } \\
\text { finance \& risk } \\
\text { management skills }\end{array}$ & $\begin{array}{c}\text { International } \\
\text { marketing skills }\end{array}$ & $\begin{array}{l}\text { International trade } \\
\text { logistics skills }\end{array}$ & $\begin{array}{l}\text { International trade } \\
\text { regulations skills }\end{array}$ & $\begin{array}{c}\text { International } \\
\text { strategic } \\
\text { management skills }\end{array}$ & $\begin{array}{c}\text { International } \\
\text { trade research } \\
\text { skills }\end{array}$ \\
\hline Mean & 2.64 & 2.75 & 2.20 & 2.7 & 3.15 & 2.62 \\
\hline $\mathrm{SD}$ & 0.62 & 0.59 & 0.70 & 0.80 & 0.69 & 0.81 \\
\hline Variance & 0.38 & 0.34 & 0.50 & 0.64 & 0.47 & 0.65 \\
\hline Range & 2.44 & 2.67 & 3.14 & 3.43 & 3.40 & 4 \\
\hline Minimum & 1.33 & 1.25 & 1 & 1.14 & 1 & 1 \\
\hline Maximum & 3.78 & 3.92 & 4.14 & 4.57 & 4.40 & 5 \\
\hline
\end{tabular}

Table 3

The Result of Regression Index to Determine the Influence of Export Skills on Growth of Export Sales

\begin{tabular}{|c|c|c|c|c|c|}
\hline Independent variable & B & Std. Error & Beta & $\mathrm{t}$ & Sig. \\
\hline International finance and risk management skills & 202 & 0.09 & 0.19 & 2.06 & 0.044 \\
\hline International marketing skills & 182 & 0.06 & 0.18 & 2.91 & 0.00 \\
\hline International trade logistic skills & 130 & 0.64 & 0.12 & 1.88 & 0.06 \\
\hline International trade regulation skills & 155 & 0.08 & 0.16 & 2.02 & 0.04 \\
\hline International strategic management skills & 144 & 0.09 & 0.14 & 1.56 & 0.12 \\
\hline International trade research skills & 200 & 0.10 & 0.19 & 1.96 & 0.04 \\
\hline
\end{tabular}

*Dependent variable: Growth of export profits

As Table 4 indicates and by examining the growth of export profits, it can be argued that there was a significant relationship between international finance and risk management skills and international marketing skills. However, with growth of export sales, there was no significant relationship between international trade logistic skills, international trade regulations skills, international strategic management skills, and international trade research skills. 
Considering the results given in Table 4 and growth of export profits, it can be claimed that there was a significant relationship between international finance, risk management skills, and international marketing skills. Having considered the growth of export sales, it can be argued that there was no significant relationship between international trade logistic skills, international trade regulations skills, international strategic management skills, and international trade research skills.

Table 4

The Result of Regression Index to Determine the Influence of Export Skills on Growth of Export Profits

\begin{tabular}{|c|c|c|c|c|c|}
\hline Independent variable & $\mathrm{B}$ & Std. Error & Beta & $\mathrm{t}$ & Sig. \\
\hline International finance and risk management skills & 0.37 & 0.36 & 0.32 & 2.10 & 0.04 \\
\hline International marketing skills & 0.22 & 0.42 & 0.20 & 1.92 & 0.04 \\
\hline International trade logistic skills & 0.09 & 0.36 & 0.12 & 0.50 & 0.26 \\
\hline International trade regulation skills & 0.22 & 0.26 & 0.18 & 1.08 & 0.28 \\
\hline International strategic management skills & 0.15 & 0.28 & 0.15 & 0.72 & 0.44 \\
\hline International trade research skills & 0.18 & 0.24 & 0.17 & 0.98 & 0.33 \\
\hline
\end{tabular}

Table 5

The Result of Regression Index to Determine the Influence of Export Skills on Expansion of Export Markets

\begin{tabular}{|c|c|c|c|c|c|}
\hline Independent variable & $\mathrm{B}$ & Std. Error & Beta & $\mathrm{t}$ & Sig. \\
\hline International finance and risk management skills & 0.21 & 0.15 & 0.19 & 1.12 & 0.12 \\
\hline International marketing skills & 0.14 & 0.35 & 0.13 & 0.39 & 0.52 \\
\hline International trade logistic skills & 0.06 & 0.37 & 0.07 & 0.22 & 0.63 \\
\hline International trade regulation skills & 0.18 & 0.23 & 0.17 & 0.77 & 0.44 \\
\hline International strategic management skills & 0.10 & 0.36 & 0.11 & 0.31 & 0.59 \\
\hline International trade research skills & 0.21 & 0.12 & 0.12 & 2.21 & 0.02 \\
\hline
\end{tabular}

*Dependant variable: Expansion of export markets

As Table 5 clearly exhibits and also considering the growth of export profits, it can be seen that there was a significant relationship between international trade research skills. However, there was no significant relationship between international finance and risk management skills, international marketing skills, international trade logistic skills, international trade regulations skills, and international strategic management skills.

Based on the beta coefficients, the influence of each of variables on the growth of export sales were as follows: international finance and risk management skills (0.19), international trade research skills (0.19), international marketing skills (0.18), international trade regulations skills (0.16), international strategic management skills (0.14), and international trade logistic skills (0.12).

According to the beta coefficients, influence of each of variables on the growth of export profits were as follows: international finance and risk management skills (0.32), international marketing skills (0.20), international trade regulations skills (0.18), international trade 
research skills (0.17), international strategic management skills (0.15), and international trade logistic skills (0.12).

Regarding the beta coefficients, influence of each of variables on the expansion of export markets were as follows: International trade research skills (0.12), international finance and risk management skills (0.19), international trade regulations skills (0.17), international marketing skills (0.13), international strategic management skills (0.11), and international trade logistic skills (0.07). Generally, it can be argued that international finance and risk management skills, international trade research skills, international marketing skills, and international trade regulations skills had the most impact on the export performance variables.

\section{Discussion and Concluding Remarks}

The present study was an attempt to identify the influence of export skills on export performance. This identification is perceived to help export companies and government trade promotion agencies to enhance their export skills training programs and also it will be useful in order to strengthen their competitive advantages in the foreign markets. The outcomes of this research display that international finance and risk management skills, international trade research skills, international marketing skills, and international trade regulations skills have the most significant impact on the export performance.

According to the literature review, the results of this research are in line with findings of Ting, Guijun, and Bojun (2010) and Samiei Nasr, Aali, and Bafandeh Zendeh (2011). Ting's findings revealed that in the higher export stage, skills in international marketing and international trade logistics were considered as being more important. However, in an early export stage, a company demonstrated more concerns on international trade policy and regulations, international finance, and international trade research. Among the export skills, some of them are considered to be the most important, in particular skills in international finance and risk management, international trade regulations, and international trade research (Samiei Nasr, Aali, \& Bafandeh Zendeh, 2011).

Based on the prioritization of export skills based on Beta coefficient, it is beneficial if exporting companies pay more attention to the skills that are at the top of this priority. For example, exporting companies can put international finance and risk management skills, international trade research skills, international marketing skills, and international trade regulations skills at the top of their educational program. The international financial skills are 
considered as the most important export skills. So, in the future studies they can be used in measuring the impact of international financial skills on export performance and prioritizing the international financial skills.

\section{References}

Aaby, N., \& Slater, S. F. (1989). Management influence on export performance: A review of the empirical literature 19781988. International Marketing Review, 6(4), 7-26.

Balassa, B. (1978). Exports and economic growth: Further evidence. Journal of Development Economics, 5, 9-181.

Bijmolt, T. H. A., \& Zwart, P. S. (1994). The impact of internal factors on the export success of Dutch small and mediumsized firms. Journal of Small Business Management, 32(2), 69-83.

Bilkey, W. (1978). An attempted integration of the literature on the export behavior of firms. Journal of International Business Studies, 9(1), 33-46.

Burton. F. N., \& Schlegelmilch, B. B. (1987). Profile analysis of non-exporters versus exporters grouped by export involvement. Management International Review, 27(1), 38-49.

Cavusgil, S. T., \& Nevin, J. R. (1981). Internal determinants of export marketing behavior: An empirical investigation. Journal of Marketing Research, 18, 114-119.

Chetty, S., \& Hamilton, R. (1993). Firm-level determinants of export performance: A meta analysis. International Marketing Review, 10(3), 26-34.

Chrisman, J. J., \& Leslie, J. D. (1989). Strategic administrative operating problems: The impact of outsiders of small firm performance. Entrepreneurship Theory and Practice, 13(3), 37-51.

Czinkota, M. R., \& Ursic, M. (1991). Classification of exporting firms according to sales and growth into share matrix. Journal of Business Research, 22(3), 243-253.

Gabriel, O., \& Simone, N. G. (2004). Factors influencing export performance in international marketing: A study of Australian firms. International Journal of Management, 21(2), 172-185.

Gancel, C. (1995). ICM management training in Russia: Traps and gaps. Journal of Management Development, 14(5), 1527.

Hendrych, M. (1994). Needed: Export education. ABA Banking Journal, 86(6) 88-99.

Katsikeas, C., Leonidou, L., \& Morgan, N. (2000). Firm-level export performance assessment: Review, evaluation and development. Academy of Marketing Science, 28(4), 493-511.

Kaynak, E. (1992). A cross regional comparison of export performance of firms in two Canadian regions. Management International Review, 32(2), 163-180.

Kedia, B. L., \& Chhokar, J. (1986). Factors inhibiting export performance of firms: An empirical investigation. Management International Review, 26(4), 33-43.

Koksal, M.H. (2006). Export training: A preliminary investigation of Turkish companies. European Business Review, 18(5), 382-394.

Kotabe, M., \& Czinkota, M. R. (1992). State government promotion of manufacturing exports: A gap analysis. Journal of International Business Studies, 23(4), 637-658.

Leonidou, L., Katsikeas, C., \& Samiee, S. (2002). Marketing strategy determinants of export performance: A meta-analysis. Journal of Business Research, 55(1), 51-67.

Li, L. (2004). An examination of the foreign market knowledge of export firms based in the people's republic of China: Its determinants and effect on export intensity. Industrial Marketing Management, 33(5), 61-72.

Li, L., \& Ogumokun, G. O. (2001). Effect of export financing resources and supply-chain skills of export competitive advantages: Implications for superior export performance. Journal of World Business, 36(3), 260-279.

Moini, A. H. (1995). An inquiry into successful exporting: An empirical investigation using a three-stage model. Journal of Small Business Management, 33(3), 9-23.

Norvell, W., Andrus, D. M., \& Gogumalla, N. V. (1995). Factors related to internationalization and the level of involvement in international markets. International Journal of Management, 12(1), 63-77. 
Piercy, N. F., Kaleka, A., \& Katsikeas, C. S. (1998). Sources of competitive advantages in high performing exporting companies. Journal of World Business, 33(4), 378-393.

Reid, T. (1994). Giving small business a fighting chance. Canadian Business Review, 21(1), 16-19.

Ross, D. G., \& Whalen, M. P. (1999). The importance of practical export skills: Some evidence from Canadian agribusiness. International Food \& Agribusiness Management Review, 2(1), 9-27.

Samiei Nasr, M., Aali , S., \& Bafandeh Zendeh, A. (2011). A Model to evaluate the readiness of Iranian enterprises to gain entry to international market: The most locally responsive skills required for export markets. Middle-East Journal of Scientific research, 10(6), 691-697.

Samiee, S., \& Walters, P. G. P. (1999). Determinants of structured export knowledge acquisition. International Business Review, 8(4), 373-397.

Theodosiou, M., \& Leonidou, L. (2003). Standardization versus adaptations of international marketing strategy: An integrative assessment of the empirical research. International Business Review, 12(2), 141-171.

Ting, Z., Guijun, L., \& Bojun, L. (2010). Importance export skills comparison in different export stage: An empirical study of Chinese firms. Journal of Chinese Economic and Foreign Trade Studies, 3(3), 204-220.

Valos, M., \& Baker, M. (1996). Developing an Australian model of export marketing performance determinants. Marketing Intelligence \& Planning, 14(3), 11-20.

Zou, S., \& Stan, S. (1998). The determinants of export performance: A review of the empirical literature between 1987 and 1997. International Marketing Review, 15(5), 333-356. 